\title{
Zbigniew Kadłubek*
}

\section{Bez języka. \\ Esej o literaturze górnośląskiej}

DOI: http://dx.doi.org/1 0.12775/LC.2019.031

Nazwę cię Ijonem, bo taki twój los.

Eurypides: Ijon (661)

\section{Miejsce gŏdki}

P

o upadku komunizmu w Polsce rozpoczął się proces budowania świadomych obywatelskości wspólnot regionalnych. Najwyrazistsze takie wspólnoty w Rzeczpospolitej Polskiej to Kaszubi i Górnoślązacy. O ile jednak Kaszubi swoją tożsamość mogą opierać instytucjonalnie na języku kaszubskim uznanym przez państwo polskie za język regionalny, Górnoślązacy pozostali w pewnej próżni zarówno jako największa w Polsce nieuznana mniejszość etniczna, jak i taka grupa, której języka nie chronią żadne prawne dokumenty.

Niezależnie jednak od politycznej dyskusji o statusie tego języka i procesów legislacyjnych, jego kodyfikacji etc. rozwija się literacka twórczość w śląszczyźnie, którą będę w tym szkicu nazywał etnolektem. Słowo „etnolekt” tylko prowizorycznie oddaje sytuację śląszczyzny. Nie jest jednak odpowiednim określeniem języka Górnoślązaków; tak samo jak „gwara”, moim zdaniem, ponieważ nie oddaje w pełni waloru komunikacyjnego mowy Górnoślązaków, czyli ich gŏdki. Zauważmy też od razu, że gŏdka (jako język i mowa) oddaje raczej język mówiony niż pisany, jest zatem skazana na ontologię intymności domowej. Ujawnia się tutaj pewna słabość. Z drugiej zaś strony - ten niejako wciąż „przedpiśmienny” etap rozwoju etnolektu górnośląskiego wyzwala pewną energię - mityczną wręcz - i tajem-

* Prof. Uniwersytetu Śląskiego, komparatysta, filolog klasyczny, kierownik Katedry Literatury Porównawczej na Wydziale Filologicznym Uniwersytetu Śląskiego w Katowicach, dyrektor Biblioteki Śląskiej w Katowicach.

E-mail: kadłubek@pseudonim.pl | ORCID: 0000-0002-0169-3748. 
niczość szyfru. Gōrnoślōnsko gŏdka (por. Kallus 2015) wiedzie swój oralny i „pierwotny” żywot jako ekspresja duchowa nawet wtedy, gdy coraz śmielej zapisywane i drukowane są już teraz śląskie słowa. Platon pochwaliłby Górnoślązaków za to, że powierzają swój język raczej żywej (roz)mowie, dialogowi, pamięci pokoleń czy tradycji, niż medialnemu wehikułowi Gutenberga. Drzemie zatem w śląskim etnolekcie ogromny potencjał narracyjny, artystyczny, wspólnotowy. Nawet jeśli sami Górnoślązacy idealizują te sprawy i przeceniają walory medialne swojego języka (co czynię także ja, pisząc te słowa). W eseju nie uwzględnię wielu nazwisk, wielu zjawisk i wielu tekstów, które powstają w śląskim etnolekcie. To pierwsza przymiarka do zarysu historii literatury śląskiej tworzonej w śląskim etnolekcie. Dodatkowo - uważam - jesteśmy w pewnej chwili przełomowej. Esej ten będzie więc subiektywnym odzwierciedleniem z początku roku 2018 procesów zachodzących w literaturze górnośląskiej, której sytuacja dynamicznie się zmienia.

\section{Literatura mniejsza?}

To paradoksalne i trudne, ale literatury górnośląskiej w etnolekcie górnośląskim nie nazwalibyśmy literaturą mniejszą. Tak może określilibyśmy literaturę śląską w ogóle (pisaną po łacinie, polsku, czesku, niemiecku, w etnolekcie śląskim i w jidysz), wziętą jako całość i koincydencja wyrastająca z jednego miejsca i z tej samej wspólnoty interpretacyjnej. Używam pojęcia literatury mniejszej za Gilles'em Deleuze'em i Félixem Guattarim. Przeczytajmy uważnie definicję literatury mniejszej francuskich filozofów: „Literatura mniejsza nie jest literaturą jakiegoś mniejszego języka, ale taką, którą jakaś mniejszość tworzy w języku oficjalnym” (Deleuze, Guattari 2016: 84). Do literatury mniejszej zaliczylibyśmy Dracha Szczepana Twardocha (w jego wersji oryginalnej, nie myślę o jego przekładzie na etnolekt śląski). Dlaczego? Ponieważ autor tej powieści, określający się jako Górnoślązak, deklarujący przynależność do górnośląskiej mniejszości etnicznej, pisze w języku oficjalnym, urzędowym, w języku polskim.

Jednak, wracając do Deleuze’a i Guattariego, literatura górnośląska, jako literatura mniejszości etnicznej, spełnia częściowo trzy kryteria literatury mniejszej. „Trzy główne wyznaczniki literatury mniejszej to [...] deterytorializacja języka” - pisali Deleuze i Guattari - „umieszczenie indywiduum w aktualności politycznej oraz kolektywne układy wypowiedzenia” (ibid.: 93). Po pierwsze: Górny Śląsk to historia nieustannej deterytorializacji. W deterioryzowaniu się Górny Śląsk osiągnął świadomość siebie. Po drugie: każdy Górnoślązak mówiący po śląsku publicznie dokonuje nolens volens jakiegoś gestu politycznego, ryzykując np. wykluczenie: „[... [ każde wydarzenie indywidualne od razu zostaje uwikłane w politykę" (ibid.: 87). Mogę tak powiedzieć z własnego doświadczenia. Po trzecie: kolektywne układy wypowiedzenia w związku ze śląszczyzną są niezwykle aktywne, brakuje bowiem śląszczyźnie (zawsze plebejskiej, nawet w najwyższych rejestrach) „warunków dla wypowiedzenia zindywidualizowanego” (ibid.: 90). Talenty przemieszczają się i wypowiadają w językach uznanych, oficjalnych. 


\section{Co to jest literatura śląska?}

Nie mam wątpliwości, że istnieje śląska literatura. Chociaż wolę ją nazywać literaturą górnośląską, gdyż horyzont historyczny Śląska to dzisiaj mglistość. Jakie są cechy tej literatury? Nie musi być pisana w śląskim etnolekcie. Tak jak literatura walijska rzadko jest pisana po walijsku, częściej po angielsku (np. Niall Griffiths), a literatura neapolitańska może się wypowiedzieć po włosku (Erri De Luca, powieściopisarz i poeta).

Może być pisana literatura śląska po śląsku, po niemiecku, po czesku czy wreszcie po polsku. Musi jednak być zaangażowana w ideę śląskiej emancypacji. Wtedy jest śląska, przynależąc do wspólnoty śląskiego sensu. Wtedy ma śląski kształt, jeśli wolno tak powiedzieć - niezależnie od tego, z jakiego powstała tworzywa. Tylko wtedy można ją nazwać śląską, gdyż polem jej pracy jest śląska podmiotowość. Ta energia emancypacyjna - czyli traktowanie śląskości jako naturalnej i rzeczywistej partykularności - wyróżnia ją od innych dookolnych literatur. Cała śląskość nie jest w stanie wyrazić się po śląsku, czyli w śląskim etnolekcie. Większe języki i większe tradycje literackie, dobrze i silnie obecne na Górnym Śląsku, zawsze będą zatem „przeszkadzać” rozwojowi literatury górnośląskiej pisanej po śląsku. Lecz z tego intersemiotycznego agonu śląskiego bierze się w ogóle śląskość - jako forma eksplikacji różnicy.

\section{Kanon górnośląski}

Z Łucją Staniczek stworzyliśmy pewną propozycję lekturową, która nosi nazwę 99 książek, czyli mały kanon górnośląski (Kadłubek, Staniczek 2011). W projekcie wzięli udział krytycy literaccy, akademicy, regionaliści, nauczyciele. Otwieraliśmy wówczas dyskusję, co służy konstruowaniu śląskiej tożsamości w przestrzeni literatury. Wśród autorów, których obejmowaliśmy śląskim kanonem, był i Homer, i Horst Bienek, i ks. Jerzy Szymik, i Ajschylos, i Ivo Andrić, i Henryk Bereska, i Petr Bezruč. Rzecz była otwarta, ponieważ liczba 99 nie jest liczbą zamkniętą i skończoną (przeciwstawienie się poetyce setnika). 99 książek, czyli maty kanon górnoślaski to swoista propozycja czytania z miejsca, w którym się jest, z Górnego Śląska, czytania ku tradycji wielości, uniwersalności i globalności świata. Dyskusja nad śląskim kanonem szybko przerodziła się w ostrą krytykę naszego projektu. Największym przeciwnikiem naszego kanonu górnośląskiego był zmarły niedawno Tadeusz Kijonka, wybitny śląski poeta i wieloletni redaktor miesięcznika „Śląsk”.

Ale doczekała się nasza książka z małym kanonem górnośląskim wielkiego dopowiedzenia w pierwszym numerze kwartalnika „Fabryka Silesia” (rok 2012), gdzie zaproponowaliśmy z Janem F. Lewandowskim, już też nieżyjącym, oryginalną, choć naiwną zapewne, listę przebojów górnośląskich tekstów literackich. Stworzyli ją różni ludzie związani z regionem, głównie jednak intelektualiści. Był to niewątpliwie ciekawy plebiscyt i niezwykły eksperyment (na podstawie redakcyjnej ankiety). Zwycięzcą okazał się Horst Bienek, pisarz niemieckojęzyczny z Gliwic. Wysoko uplasowali się Henryk Waniek (piszący po polsku), Janosch (piszący po niemiecku), August Scholtis (piszący po niemiecku), Stanisław Bieniasz (piszący po polsku), Hans Niekrawietz (piszący po niemiecku), Ota Filip (piszący 
po czesku), Gustaw Morcinek (piszący po polsku), Kazimierz Kutz (piszący wprawdzie po polsku, ale stylizujący na śląski etnolekt niektóre partie swoich tekstów), a także Alojzy Lysko (piszący po polsku i w etnolekcie śląskim). Były to czasy sprzed wydania Dracha Szczepana Twardocha i sprzed kryminałów Marcina Melona.

\section{Śląska Nowa Fala}

Około roku 2010 przyszło to, co nazywam Śląską Nową Falą. Otwiera ją - jest to nieskromne, ale konieczne - druga edycja moich napisanych w etnolekcie śląskim (zapis fonetyczny) Listów $z$ Rzymu ${ }^{1}$, powieści epistolarnej opublikowanej przez nowo powstałe wydawnictwo Silesia Progress (Kadłubek 2012). Była to pierwsza książka wydana przez wydawnictwo Piotra Długosza (Kotórz Mały w województwie opolskim). Działalność tego wydawnictwa rozpoczęła nowy rozdział w historii literatury górnośląskiej. Dodajmy, że istotną sprawą było także publikowanie przez Silesia Progress przekładów arcydzieł literatury światowej na śląski etnolekt (Ajschylos, Dante, Dickens etc.).

Literatura górnośląska pisana w etnolekcie śląskim przez autorki i autorów Śląskiej Nowej Fali ma charakter antysystemowy i offowy. Bez szans na przełożenie ekonomiczne. Nie piszę teraz o ideach, poziomie artystycznym, zaangażowaniu ideologicznym i politycznym, genderowym etc. Chodzi mi jedynie o to, że autorzy piszący po śląsku podjęli ryzyko: zawęzili krąg odbiorców świadomie, eksperymentując z małym językiem. Działają poza ogólnopolskim rynkiem wydawniczym, nie dostrzegają ich instytucje i mainstreamowi krytycy literaccy, wykluczają ich kapituły ogólnopolskich nagród literackich, ważne literackie festiwale (nawet wrażliwy na wykluczone głosy literacki Conrad Festival).

Jedyna znacząca nagroda literacka na Górnym Śląsku, jaka pojawiła się w ostatnich latach, ufundowana przez prezydenta Rybnika, to Górnośląska Nagroda Literacka Juliusz². Dzięki mądrości i otwartości członków kapituły tej nagrody dostrzega się tutaj śląską twórczość literacką. Dowodem tego choćby nominacja do edycji nagrody w 2017 roku Alojzego Lyski, upartego awangardzisty, który od wielu lat trzyma się śląszczyzny jako literackiego tworzywa.

\section{Elegijność jako cecha śląskiej wypowiedzi regionalnej}

Alojzy Lysko urodził się w 1942 roku w Bojszowach (ziemia pszczyńska). Znany jest wszystkim śląskim czytelnikom głównie z cyklu powieściowego w etnolekcie śląskim pt. Duchy wojny. Lysko jest upartym awangardzistą pisania po śląsku i o Śląsku. Do tego

\footnotetext{
1 Pierwsze wydanie ukazało się w roku 2008.

2 Nazwa nagrody nawiązuje do postaci Juliusa Rogera, dziwiętnastowiecznego lekarza w Rybniku, tłumacza, entomologa, etnologa, którego ze Szwabii na Górny Śląsk sprowadził książę raciborski Wiktor I (Viktor Moritz Karl I. Herzog von Ratibor).
} 
pionierem pisania o sprawach najbardziej przemilczanych. Można by nawet powiedzieć, nieco przesadzając, że jest ojcem literatury śląskiej w tym nowym emancypacyjnym rozumieniu.

Niepodważalnie głównym znakiem rozpoznawczym tej literatury, którą uznalibyśmy za specyficznie śląską, u samych jej początków była elegijność. W recenzji książki Kazimierza Kutza pisał Karol Alichnowicz (2010: 128): „Piąta strona świata jest narracją elegijną, której smutek pogłębia świadomość bezpowrotnie utraconego świata niedającego się ocalić przed nicością". Można śmiało, według mnie, powiedzieć, że całą literaturę górnośląską ostatnich dekad, może nawet całego powojennego półwiecza, przenika ta sama nuta elegii oraz nostalgii, walka z nieprzepracowanymi traumami. Nie inaczej jest z prozą Lyski. Elegijnością jego pisarstwa, kondycją i horyzontem jego wizji twórczej, była jakaś boleść utraty rozpamiętywana i przepracowywana na różne sposoby.

Od razu warto również zapytać od dwie ważne sprawy, gdy się cokolwiek chce powiedzieć o literaturze śląskiej, sprawy - w moim subiektywnym rozumieniu - konstytutywne.

To, co regionalne w literaturze (w kwestii artystycznej komunikacji) - jak pisała Stefania Skwarczyńska - ma dosyć prosty cel związany z określeniem „wpływu ziemi, krajobrazu, obyczajów i zwyczajów w danym regionie na dzieło literackie z nim związane bądź tematyką, bądź przez pochodzenie ich autorów, czy też z nim ich zżycie”. Jednak w śląskim przypadku dochodzi odtraumatyzowywanie poprzez pisanie. Literackie ujęcie regionalności, często wykorzystywane na Górnym Śląsku w edukacji regionalnej, opiera się na ujęciu wspominkowym/wspomnieniowym, a nie nowych tekstach. Często są to teksty, niestety, o słabej jakości estetycznej. Prowadzi to bowiem do utwierdzenia w przekonaniu, że region to coś gorszego, coś ograniczającego. Charyzmatyczny regionalista mazurski i poeta, Kazimierz Brakoniecki, mówi, że „Górny Śląsk [... ] nie jest ziemią wyimaginowaną, terra nullius zapełnioną mitotwórstwem indywidualnym i wspólnotowym $\mathrm{w}$ imię ratowania najlepszych cech idealizowanego wielokulturowego dziedzictwa, lecz tragiczną i zdradzoną śląską Krainą Nod”. U Lyski jest podobnie - afirmuje dawność. Nawet w wydanej ostatnio i napisanej z kobiecej perspektywy Ślaskiej Niobe. Wystawia ją z powodzeniem katowicki Teatr Korez w reżyserii Mirosława Neinerta pod tytułem Mianujom mie Hanka - z Grażyną Bułką w roli głównej. Opowieść poruszająca, wyciskająca łzy z oczu widzów, ale opierająca się na dawnych kliszach: znamy je przecież z granych w śląskim etnolekcie Cholonka albo z Polterabend autorstwa Stanisława Mutza. Nowością byłoby spojrzenie kobiece na świat historii rozwałkowującej śląskość i rodzinę śląską. Jednak i Lysko, i Neinert przebili się, w mojej opinii, do nowszej reprezentacji tego, co śląskie. Gorzej, że i bohaterka opowieści (monodramu), i śląskość immanentna, opowiedziana ustami kobiecymi, sytuuje się w roli pasywnej ofiary. Nie tworzy historii, to historia ją spycha na krawędź bytu. Cóż rzec? Tak było na Górnym Śląsku. Ale w ten sposób nie wyjdziemy ze śląskiej gettyzacji - ani nie wyrecytujemy niczego innego: jedynie długą elegię. Jednak atutem - oprócz kobiecości - jest tutaj mowa: żywa śląska mowa. Uniwersalne, egzystencjalne jest „wygodane” ze sceny (i z książki Lyski) po śląsku. Atutem jest także minimalizm: wielka oszczędność retoryki. „Mianujom mie Hanka - pisała Marta Odziomek w recenzji tego spektaklu - to kolejny ważny głos na temat Śląska i Ślązaków. Poruszający i intymny. Prosto i dobitnie wyjaśniający, o co w tym całym za- 
mieszaniu chodzi. I będący - z drugiej strony - elegią o odchodzeniu. Człowieka, ale i całego regionu, który powoli zmienia się na naszych oczach”.

I zatem książka Lyski, i monodram zrobiony na jej podstawie przez Neinerta - to wielka regionalna lekcja. Zgadzam się, że nie zawsze literatura regionalna wypowiada się w regionalnym języku, chociaż Lysko etnolektu śląskiego nigdy się nie wstydził. Literatura regionalna może się wyrażać w języku narodowym, języku państwowym, jak np. czynił to w swej twórczości Fulvio Tomizza (1935-1999), niemal rówieśnik Lyski. Może literatura regionalna przyjmować formy hybrydyczne: gdzie w poezji lub w prozie pojawia się obok większego języka język mniejszy - język regionalny bądź dialekt. $\mathrm{Z}$ tej hybrydyczności korzystał Lysko wielokrotnie (podobnie jak Kutz czy Twardoch). Te formy mieszane nie są wcale uprzywilejowane, nie chcę tego powiedzieć, ale patrząc pragmatycznie (a także rynkowo), zyskują więcej odbiorców. Podobnie tworzy wspomniany też wyżej neapolitański pisarz Erri De Luca, który pisze po włosku i tylko „wprawia” zdania w dialekcie neapolitańskim, gdy pragnie coś szczególnie oddać w barwie, w rytmie swego miasta.

Lysko nauczył nas, nauczył mnie, pewnej swobody, autonomii i prostolinijności w posługiwaniu się etnolektem śląskim. Dodał mi odwagi. Ośmielił mnie. Poza tym, jego mądre listy, które śle do mnie tradycyjną pocztą, są za każdym razem nie jakimś pouczeniem, nie jakąś recenzją, lecz czułą podpowiedzią ojcowską, najczęściej afirmacją, inspiracją - i potrzymaniem w śląskim myśleniu, które wciąż ze Śląska wycieka, niknie, ucieka.

\section{Literatura górnośląska w śląskim etnolekcie w nowych mediach}

Współczesne teksty powstające w etnolekcie śląskim panoramicznie omówił i pogrupował Artur Czesak w swej językoznawczej monografii (Czesak 2015). Jest to właściwie pierwszy naukowy zarys historii literatury śląskiej pisanej w śląskim etnolekcie. Autor podzielił teksty na poezję i prozę. Słusznie też Czesak wskazał na Internet jako przestrzeń, która przyspiesza rozwój inicjatyw językotwórczych (ibid.: 105). Bardzo wiele tekstów w etnolekcie ma swoich odbiorców przede wszystkim w Intenecie.

\section{Pisanie w etnolekcie - twórczość ludowa?}

Pisanie w śląskim etnolekcie jeszcze dekadę temu uchodziło za twórczość ludową. Pokoleniowo i estetycznie jednak dużo się zmieniło. W 2008 roku Katarzyna Szkaradnik wydała w Ustroniu poemat Milka ze Trześni. We sztyróch kónskach wierszym, napisany w cieszyńskiej odmianie etnolektu śląskiego. To autorka młodszego pokolenia, urodzona w Ustroniu w 1987 roku, akademiczka. Ten znakomity tekst nie doczekał się, o ile mi wiadomo, żadnych recenzji. Ktoś mógłby pomyśleć, że to dzieło dziewiętnastowieczne, rdzennie ludowe, a tutaj się okazuje, że autorka jest literaturoznawczynią. 
Wielu piszących po śląsku uświadomiło sobie artystyczną poliwalencję śląszczyzny. Wzięło dziarsko i bez kompleksów śląskie słowa za tworzywo. Pomagają temu nowe media. Najwybitniejszym i najbardziej uzdolnionym autorem Śląskiej Nowej Fali jest Marcin Melon, twórca pisanych w etnolekcie śląskim kryminałów3. Pojawiło się zatem około dekady temu wielu autorów tworzących na wysokim poziomie artystycznym, piszących po śląsku (związanych przede wszystkim z Wydawnictwem Silesia Progress Piotra Długosza). Towarzyszyło temu zjawisku pojawienie się wybitnych tekstów także w języku polskim, jak np. wspominany już Drach (Twardoch 2014), który jest powieścią arcyśląską.

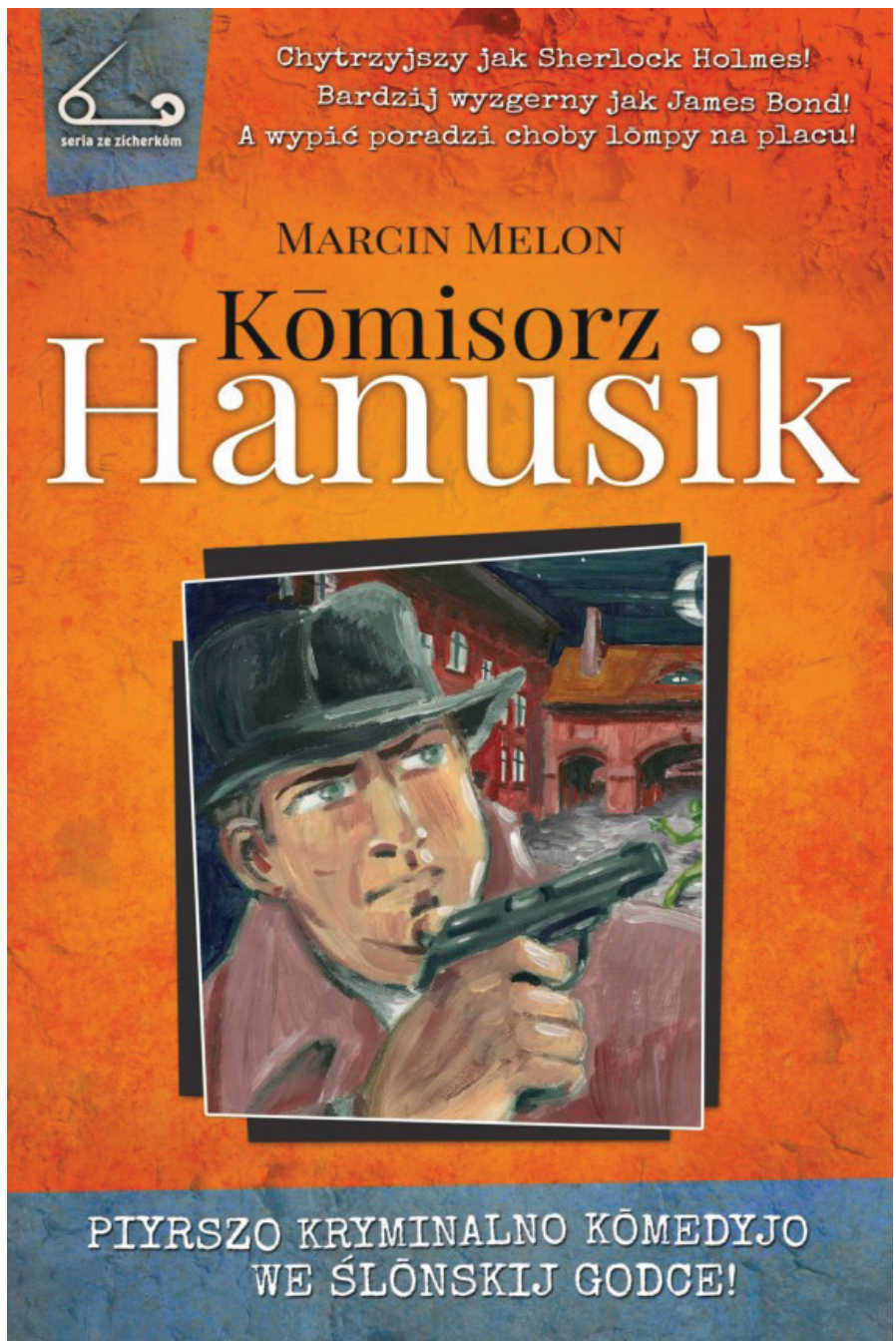

Okładka pierwszej powieści kryminalnej w etnolekcie śląskim, czyli Kōmisorz Hanusik Marcina Melona

\footnotetext{
3 Pierwsza część serii: Kōmisorz Hanusik (Melon 2014).
} 


\section{Sprawa Dracha}

Niedługo (stan z początku 2018) nakładem Wydawnictwa Literackiego wyjdzie przekład Grzegorza Kulika powieści Szczepana Twardocha pt. Drach na etnolekt śląski. To może być przełomowe dla literatury pisanej w tym etnolekcie. Powieść ta bowiem stała się ważną książką dla wielu Górnoślązaków - i swoistym lustrem, w którym może się przejrzeć śląska konarowa, rosochata i przedziwnie widlasta genealogia. W całym swym pogmatwaniu, poplątaniu i wykrzywieniu. Drach bowiem to mitologia o działaniu terapeutycznym dla wielu śląskich - i nie tylko śląskich - czytelników znających pograniczne zawiłości bytu, w którym żaden kod nie jest oczywisty i przyjęty wiekuiście; w którym logos musi pozostać czymś dyskretnym, półtajnym i cichym. Gdy logos sercowy i rozumowy milknie, gdy logos nie rozjaśnia losu, pojawia się duży apetyt na mitologię. Zaczyna się wtedy pozornie niedorzeczne poszukiwanie mitologicznego świętego czasu początku jako potrzeba wiedzy, gdzie się jest i kim się jest. Wytryskiwanie czasu inicjalnego i zalążkowego dla śląskości nie znalazło jeszcze nigdy w literaturze (pisanej po czesku, polsku, niemiecku, śląsku) swojego wyrazu - aż do momentu ukazania się Twardochowego Dracha, dzieła antylinearnego, czyli odpowiadającego najdokładniej śląskiej historii oraz tradycji.

Opisując czy analizując fenomen śląskości, należałoby czym prędzej w ogóle oddalić od siebie śląskość, silnie ją zanegować, a także - co chyba najważniejsze - ujawnić i obnażyć wszystkie jej ograniczenia. W Drachu ta strategia się pojawia. Wszak jest to w oryginalnej wersji polska powieść, po polsku napisana, gdzie tylko dialogowe partie mieszają języki (niemiecki, archaiczny śląski, śląski spolonizowany, w którym mówi obecnie większość Górnoślązaków). Z drugiej jednak strony (chociaż trudno tu mówić o stronach, trzeba by raczej mówić o innym odcinku okręgu) działa w Drachu atletyczne i skondensowane przylgnięcie do śląskości. To tak ścisłe mityczne przylgnięcie, że możemy je uznać za niwelujące śląskość. O to właśnie chodzi. Taka najbliższa bliskość (obecna w hemoglobinie) - staje się oddaleniem.

Zawsze cały problem z mitem polega na tym, iż poszukujemy właśnie mitycznej odpowiedzi na pytania o charakterze metafizycznym. Może istotnie jest tak, jak sądzi francuski epistemolog Georges Gusdorf (1912-2000), że mitologia to pierwsza metafizyka, a metafizyka to druga mitologia. Taka zatem jest powieść Twardocha: ma charakter pierwszej metafizyki. I ten walor książki czytelnik śląski i ten spoza Śląska, czytelnik wyrobiony lub nie - dostrzegł, przeżył, a może nawet przecierpiał. Bo jak mógł nie przeżyć spotkania oko w oko z mocarnym „drachem” (potworem o wielu oczach, władającym wieloma narracjami, pełzającym pomiędzy datami, arcysmokiem komunikacji ziemia-krew, kiedyś-teraz, mistyczne-somatyczne)? Drach przypomina pisarstwo i natężenie mi(s)tyczno-wspólnotowe - choć tylko w jakimś stopniu - Ferdinanda Camona, szczególnie jego Un altare per la madre z 1978 roku, gdzie także dochodzi do niezwykłego rytualnego zagęszczenia symboli agrarnych.

Znany krytyk literacki Dariusz Nowacki stwierdził, że Drach to nie jest śląska czy górnośląska epopeja. Sądzę jednak, że się mylił. Drach jest epopeją, której nieśląski czytelnik za epopeję nie uzna. Drach jest teogonią, w której bogów nieśląski czytelnik nie uwierzy. Co nie znaczy, że tej egzotycznej opowieści z przyjemnością nie przeczyta, gdyż 
ludzkie związki cyrkulacyjne z naturą, przyrodą, swoisty (śląski i nieśląski) szamanizm i animizm mają charakter uniwersalny.

Wielu czytelników oraz krytyków sądziłoby może, że Drach (w oryginalnej wersji) JUŻ jest po śląsku. Po co jeszcze jakby wersja podwójnie śląska? Moja refutacja brzmiałaby: tłumaczenie Dracha na śląski etnolekt to próba zmierzenia się ze śląskością i uniwersalnością tej powieści. Paradoksalnie śląska wersja Dracha staje się probierzem jej śląskiego odniesienia dziejowego. I ta wersja w (nieuznanym wprawdzie oficjalnie) śląskim etnolekcie mocno poszerza jej znaczenia. Weryfikuje jej śląski wymiar i ten wymiar powszechny jednym gestem. Oczywiście, być może, coś także tracimy z międzykodowego pobłysku oryginału, gdzie sąsiadują ze sobą słowa polskie, śląskie, niemieckie. Ale zyskujemy praźródłowy głos idiomu, który - jak mniemam - byłby istotny dla Szczepana Twardocha; słyszymy prawdziwe narzecze drachowe.

Czym jeszcze byłaby śląska wersja Dracha? Kodyfikacja etnolektu śląskiego to proces, który się jeszcze nie zakończył. Śląszczyzna to komunikacyjne narzędzie in statu nascendi. Debaty, roztrząsania, kłótnie, jak zapisywać śląskie słowa trwają i nie skończą się szybko. Być może właśnie zapis (ten ślabikorzowy), który pojawia się w przekładzie Dracha autorstwa Kulika, przyczyni się do wielu rozstrzygnięć związanych z zapisem śląskich słów, ustabilizuje literacką śląszczyznę. Bo - jak wiadomo - żeby się pojawił literacki język, potrzebne jest wielkie literackie dzieło (weźmy tylko pod uwagę język włoski i dzieło Dantego).

\section{Bibliografia}

Alichnowicz, Karol 2010. „Śląski blues”. Odra 7/8.

Czesak, Artur 2015. Wspótczesne teksty śląskie na tle procesów językoznawczych i standaryzacyjnych wspótczesnej stowiańszczyzny. Kraków: Księgarnia Akademicka.

Deleuze Gilles, Félix Guattari 2016. Kafka. Ku literaturze mniejszej. Przeł. Anna Zofia Jaksender, Kajetan Maria Jaksender. Wstęp, redakcja naukowa, sprawdzenie zgodności z oryginałem Cezary Rudnicki. Kraków: Esperons Ostrogi.

Kallus, Bogdan 2015. Stownik gōrnoślōnskij gŏdki. Stownik polsko-górnośląski. Stownik górnośląsko-polski. Chorzów: Pro Loquela Silesiana.

Kadłubek, Zbigniew 2012 [2008]. Listy z Rzymu. Katowice: Silesia Progress.

Kadłubek, Zbigniew, Łucja Staniczkowa (red.) 2011. 99 książek, czyli mały kanon górnośląski. Katowice: Wydawnictwo Księgarnia św. Jacka.

Melon, Marcin 2014. Kōmisorz Hanusik. Katowice: Silesia Progress.

Szkaradnik, Katarzyna 2008. Milka ze Trześni. We sztyróch kónskach wierszym. Ustroń: Galeria Na Gojach.

Twardoch, Szczepan 2014. Drach. Kraków: Wydawnictwo Literackie. 